\title{
Postoperative Fever and Systemic Inflammatory Response Syndrome after Ureteroscopy for Stone Disease in the Geriatric Population: Risk Factors and Determinants
}

\author{
Geriatrik Popülasyonda Taş Hastalığı için Uygulanan Üreterorenoskopi Sonrası Gelişen \\ Postoperatif Ateş ve Sistemik Enflamatuvar Cevap Sendromu: Risk Faktörleri ve Belirleyiciler
}

\author{
(1) Reha Girgin, (1) Engin Denizhan Demirkiran \\ Zonguldak Bülent Ecevit University Faculty of Medicine, Department of Urology, Zonguldak, Turkiye
}

\section{What's known on the subject? and What does the study add?}

Endoscopic procedure should be kept as short as possible in geriatric patients, and indications for postoperative Double-J catheter placement should be reduced as much as possible.

\begin{abstract}
Objective: The purpose of this study was to determine the perioperative risk factors for postoperative fever (POF)/systemic inflammatory response syndrome (SIRS) among geriatric patients after semi-rigid ureterorenoscopy with laser lithotripsy (RURSLL).

Materials and Methods: We retrospectively reviewed data of 139 procedures from 129 consecutive geriatric patients who had undergone RURSLL for stone disease in our department. Preoperative and intraoperative characteristics between patients with and without POF/SIRS were compared using univariate analyses. The significant variables on univariate analyses were included in a multivariate logistic regression analysis to evaluate the risk factors associated with POF/SIRS following RURSLL.

Results: Twenty-nine (21\%) patients had POF/SIRS after RURSLL. Patients were found with higher percentage of comorbidities, body mass indices, and lower estimated glomerular filtration rates. On univariate analysis, positive preoperative urine culture, stone size, operation time, and the presence of postoperative double-J (DJ) stent were found to be significant variables ( $p=0.004 ; p=0.016 ; p=0.01 ; p=0.01$, respectively). On multivariate analysis, positive preoperative urine culture [odds ratio (OR): $8.36 ; 95 \%$ confidence interval $(\mathrm{Cl}): 2.20-31.79 ; \mathrm{p}=0.002)$ and postoperative DJ stent insertion (OR: $6.14 ; 95 \% \mathrm{Cl}: 1.16-32.57 ; \mathrm{p}=0.033$ ) were found to be the most significant dependent variables.

Conclusion: We found that positive preoperative urine culture and postoperative DJ stent insertion were the most important determinants for infectious complications after RURSLL in geriatric population. So, the procedure should be kept as short as possible, and indications for postoperative DJ catheter insertion should be reduced as much as possible.
\end{abstract}

Keywords: Postoperative fever, Systemic inflammatory response syndrome, Ureterorenoscopy, Geriatric

\section{Öz}

Amaç: Çalışmanın amacı geriatrik hastalarda semi-rijit üreterorenoskopi (URS) sonrası postoperatif ateş/sistemik enflamatuvar cevap sendromu (SIRS) için perioperatif risk faktörlerini belirlemektir.

Gereç ve Yöntem: Kliniğimizde taş hastalığı nedeniyle uygulanan 129 ardışık geriatrik hastaya uyguladığımız 139 prosedüre ait veriler retrospektif olarak incelendi. Postoperatif ateş/SIRS olan ve olmayan hastalar arasında ameliyat öncesi ve ameliyat sonrası özellikler tek değişkenli analizler kullanılarak karşılaştıııldı. Risk faktörleri çok değişkenli lojistik regresyon analizine tek değişkenli analizlerde anlamlı değişkenler dahil edilerek değerlendirildi.

Bulgular: Yirmi dokuz (\%21) hastada postoperatif ateş/SIRS gelişti. Komplikasyon gelişen hastalarda daha yüksek komorbidite yüzdesi, vücut kitle indeksleri ve daha düşük tahmini glamerüler filtrasyon oranları gözlendi. Tek değişkenli analizde pozitif preoperatif idrar kültürü, taş boyutu,

Correspondence: Reha Girgin MD, Zonguldak Bülent Ecevit University Faculty of Medicine, Department of Urology, Zonguldak, Turkiye Phone: +90 5378865912 E-mail: mujdereha@hotmail.com ORCID-ID: orcid.org/0000-0003-1132-8629

Received: 31.01 .2020

Accepted: 03.03.2020

Cite this article as: Girgin R, Demirkıran ED. Postoperative Fever and Systemic Inflammatory Response Syndrome after Ureteroscopy for Stone Disease in the Geriatric Population: Risk Factors and Determinants. J Urol Surg 2020;7(3):177-183.

๑Copyright 2020 by the Association of Urological Surgery / Journal of Urological Surgery published by Galenos Publishing House. 
operasyon süresi ve postoperatif double-st stent varlığı anlamlı bulundu ( $p=0,004 ; p=0,016 ; p=0,01 ; p=0,01)$. Çok değişkenli analizde ise pozitif preoperatif idrar kültürü [Olasılık oranı (OR): 8,36 \%95 Güven aralığı (CI): 2,20-31,79; $p=0,002$ ] ve postoperatif Double-J stent yerleştirilmesi (OR: 6,14; \% $95 \mathrm{Cl}: 1,16-32,57 ; p=0.033)$ en anlamlı bağımsız değişkenler olarak izlendi.

Sonuç: Ameliyat öncesi pozitif idrar kültürü ve postoperatif DJ stent yerleştirilmesi geriatrik popülasyonda URS sonrası enfeksiyöz komplikasyonlar için en önemli belirleyicilerdir. Bu nedenle geriatrik hastalarda prosedür mümkün olduğunca kısa tutulmalı ve postoperatif DJ stent yerleştirme endikasyonları mümkün olduğunca azaltılmalıdır.

Anahtar Kelimeler: Postoperatif ateş, Sistemik enflamatuvar cevap sendromu, Üreterorenoskopi, Yaşlı

\section{Introduction}

According to a published data, the number of older persons-aged 60 years or more-has increased substantially in recent years and is projected to exceed 2 billion by 2050 (1). With the increasing population in this age group, the prevalence of urolithiasis is expected to increase 10\%-12\% (2). The elderly people will have limited function in different organ systems, and agingrelated comorbidities will cause problems in perioperative and/ or postoperative follow-up after therapeutic approaches (3). In addition, impairment of cardiopulmonary and renal functions may lead to increase in perioperative complication rates associated with significant operations (4).

The least invasive treatment option in the management of upper urinary tract stones included extracorporeal shock wave lithotripsy (ESWL). Erstwhile, ESWL was recommended as a firstline treatment for the treatment of kidney stones smaller than $20 \mathrm{~mm}$ (5). Flexible ureterorenoscopy (FURS) has been shown to be a viable alternative for these patients because of advances in ureterorenoscopy (URS) (6). Albeit FURS is highlighted in the modern literature, rigid URS (RURS) is commonly preferred for distal and proximal ureteral stones. Current literature has shown that RURS is a safe and efficacious choice for proximal ureteral calculi $(7,8)$. While RURS cannot be used in renal stones because of its limited maneuverability and tough access to middle and lower calyces, it can reach the kidney with ease in some cases. Besides, RURS has the superiority of larger working channel and equipment. In addition, better images can be achieved because of the higher irrigation flow. A standout among the most widely recognized complications prompting unplanned hospitalizations is postoperative fever (POF) or systemic inflammatory response syndrome (SIRS) (9-12). Latest analyses show that 3.4\%-14.2\% of emergency department visits are caused by POF $(13,14)$. More than $40 \%$ of patients with fever are admitted to hospital (15). After RURS, SIRS affects in $8.1 \%$ of patients (16). Early recognition and timely administration of medicine for POF/ SIRS are important to avoid sepsis development that conveys a mortality rate of $28.3 \%-41.1 \%$ (17). Few investigations have inspected an assortment of patient and surgical features trying to distinguish people with high risk. The aim of this research was to define POF/SIRS predictors for stone disease especially in the geriatric population after rigid ureterorenoscopy with laser lithotripsy (RURSLL).

\section{Materials and Methods}

After the approval of the ethics committee (protocol number: 2019-84-22/05, date: 22.05.2019), we retrospectively analyzed the collected data of 926 patients who underwent 1163 RURSLL between June 2004 and November 2018 in our clinic. Informed consent was obtained before oparation from all individual participants included in the study.

Investigation was carried out with cross-checking the data by using electronic operating notes, laboratory files, and hospital discharge documents. Patients with missing information or out of geriatric age group were excluded from the study. In the gathering, 251 patients were present. At long last, 129 appropriate patients were enrolled for our study.

Stone size and stone-free state (SFS) were routinely evaluated by ultrasound and/or simple kidney-ureter-bladder radiography. All patients' urine were regularly cultivated, and this was handled before RURSLL if the result was positive.

All ureteroscopic procedures were performed with antibiotic prophylaxis under general anesthesia in the lithotomy position. Ureteric dilation is not a standard practice in the unit. Before navigating the ureter, a standard sensor tip guide wire (Zip Wire, Boston Scientific, Marlborough, MA, USA) is routinely embedded into the affected ureteric orifice with a $20 \mathrm{~F}$ cystoscope (Karl Storz). 9.5 F rigid Wolf ureteroscopes were used. The irrigation fluid was heated to core body temperature in order to prevent intraoperative heat loss. Stones were broken with a holmiumyttrium-aluminum garnet laser [Versa PulseHolmium Powersuite $100 \mathrm{~W}$ or $20 \mathrm{~W}$ Lumenis (UK) Ltd., Elstree, UK] utilizing a 500u3 fiber at $15 \mathrm{~W}$ laser control $(1,200-1,400 \mathrm{~mJ}$ and $8-12 \mathrm{~Hz}$ frequency). Choice to embed a Double-J (DJ) ureteric stent was made by the operator relying upon the length of operation, the grade of ureteric edema, and magnitude of the manipulation.

SFS was precised both endoscopically at the end of the operation and radiologically preceding discharge of the patients. SFS has been described as <2-mm-size fragments (16-18).

The primary outcome was POF or SIRS and identified 7 days after RURSLL. SIRS was defined as the occurrence of at least two of the following criteria: fever $>38^{\circ} \mathrm{C}$, pulse $>90$ beats/ minute, respiratory rate $>20$ breaths/minute or $\mathrm{PaCO}_{2}<32$ 
$\mathrm{mmHg}$, or white blood cell count $>12,000 / \mathrm{mm}^{3},<4,000 / \mathrm{mm}^{3}$, or $>10 \%$ bands. Since many postoperative patients fulfill these requirements, we restricted the result to clinically important POF/SIRS defined as instant postoperative admission, hospital readmission, or emergency visit within 7 days. Manual chart analysis was conducted to verify that patients met POF or SIRS requirements.

Demographic characteristics included age, gender, body mass index (BMI), estimated glomerular filtration rate (eGFR), and the Charlson comorbidity index including age. Earlier, urologic and stone procedures were identified. Preoperative characteristics included stone laterality, largest stone size, stone location, presence of positive preoperative urine culture, presence of multidrug resistant (MDR) positive urine culture, and presenting. At the conclusion of the RURSLL, intraoperative characteristics included surgery duration and stent placement. Types of bacteria in preoperative cultures of patients with and without POF/SIRS were examined.

\section{Statistical Analysis}

Perioperative characteristics between patients with and without POF or SIRS were compared using univariate Mann-Whitney test, chi-square, or Fisher's Exact test. All significant factors associated with POF/SIRS following RURSLL with $p<0.05$ on univariate analyses were then included in a multivariate logistic regression analysis with a backward stepwise approach to select the significant ones. SPSS software version 19.0 (IBM, Armonk, NY, USA) was used for analysis with $p<0.05$ being considered statistically significant.

\section{Results}

Among the 129 patients who underwent 139 procedures, the male-female ratio was 1.68:1 with a mean age of 69.9 years. The mean Charlson comorbidity index score of 129 patients was $2.7 \pm 0.8$. Anatomical abnormality was found in $7 / 129(5.4 \%)$ patients. Mean cumulative stone size of patients was $13 \pm 6.2$ (range: $5-30 \mathrm{~mm})$ and $23(16.7 \%)$ with multiple stones. Fortytwo cases (30.4\%) had been stented preoperatively. The place of the index stone was $29.7 \%$ in the upper ureter, $17.4 \%$ in the middle ureter, $39.9 \%$ in the lower ureter, and $4.3 \%$ in the renal pelvis. Of the 19/129 (13.8\%) patients with positive urine culture, $11(8 \%)$ had preoperative MDR infection, of which Escherichia coli and Enterococcus species represented as the most common pathogens. These were managed with the suitable antibiotics according to sensitivity and microbiology advice, and scheduled URS was performed upon verification of sterile urine. The SFR after the first URS was 98 (71\%). Of the rest of the patients, 31 required a subsequent operation and 9 required a third strategy to be stone free. Accordingly, the final SFR was 99\%, requiring
1.34 procedures per patient to be stone free. One hundred three $(76.4 \%)$ had ureteric stent placed at the end of the procedure. The average hospital stay duration was 4.4 days (range: 2-13). Within the 139 procedures, $29(21 \%)$ were complicated with fever/SIRS (case group).

In the case group, patients had a larger median stone size compared to control group patients, although this difference was small and median stone size was $13 \mathrm{~mm}(p=0.016)$ for both groups. In five cases with evidence of pyonephrosis, in nine cases with severe hydronephrosis, and in the remaining majority $(n=28)$ to allow passive ureteral dilation to facilitate the passage of URS preoperative DJ stents ( $n=42,30.4 \%$ of 139) were inserted. Postoperative DJ stents were placed in 63 cases $(61.2 \%)$ to ease the passage of stone fragments, whereas DJ stents were needed in all cases with intraoperative complications $(n=40,63.5 \%)$ including mucosal damage of ureter $(n=26.65 \%)$ and mucosal bleeding $(n=14.35 \%)$. There were no catastrophic ureteral injuries in any patient, such as avulsion or perforation. Patients in the case group were susceptible to have a positive preoperative non-MDR urine culture $(31 \%$ vs $9.2 \%, p=0.004)$ and MDR urine culture (20.7 vs 4.6\%, $\mathrm{p}=0.011)$. By and large, after RURSLL, 29 (21\%) procedures experienced postoperative infectious complications. Of the 29 infectious complicated procedures, $4(13.8 \%)$ had pyuria and $25(86.2 \%)$ had SIRS (Table 1).

Postoperative POF/SIRS after RURSLL were seen in 20 of 120 (16.67\%) patients with negative preoperative urine cultures, 3 of 8 (37.5\%) patients with preoperative non-MDR urine cultures, and 6 of 11 (54.54\%) patients with preoperative MDR urine cultures. In particular, 68.4\% (13/19) of positive preoperative urine cultures of patients in whom POF/SIRS developed consisted of gram-negative pathogens. No patient experienced sepsis.

On multivariate analysis, positive preoperative urine culture (OR: 8.364, 95\% Cl: 2.2-31.79; $\mathrm{p}=0.002$ ), operation time (OR: 1.03, 95\% Cl: 1.01-1.04; $p=0.002)$, postoperative DJ stent insertion (OR: 6.138, 95\% Cl: 1.15-32.56; $\mathrm{p}=0.033$ ), and $\mathrm{BMI}$ (OR: $1.15,95 \% \mathrm{Cl}: 1.03-1.29 ; p=0.016$ ) were found to be significant with the dependent variable as the postoperative infectious complications after controlling for stone size, eGFR, and positive preoperative MDR urine culture (Table 2).

\section{Discussion}

We examined a single-institution contemporary arrangement of patients undergoing RURSLL for the management of ureteral calculi at any level. Our goal was to figure out which demographic, preoperative, and intraoperative characteristics were the best predictors of POF/SIRS in the geriatric age gathering. We found that the strongest predictors of POF/ SIRS after RURSLL for stone disease were longer surgical times, 


\begin{tabular}{|c|c|c|c|c|}
\hline Variable & $\begin{array}{l}\text { Total cohort } \\
(n=139)\end{array}$ & $\begin{array}{l}\text { POF/SIRS } \\
(n=29)\end{array}$ & Control $(n=110)$ & $\mathbf{p}$ \\
\hline Age in years, median (IOR) & $69.9 \pm 5,6$ & $70.8 \pm 5.9$ & $69.75 \pm 5.5$ & 0.364 \\
\hline Gender, female, $\%$ & $48(36.2 \%)$ & $13(50 \%)$ & $35(33 \%)$ & 0.129 \\
\hline Body mass index, $\mathrm{kg} / \mathrm{m}^{2}$ (IOR) & $25.6 \pm 4.5$ & $27.8 \pm 4.8$ & $25 \pm 4.2$ & 0.003 \\
\hline eGFR, $\mathrm{mL} / \mathrm{min}$ & & & & 0.034 \\
\hline$>60$ & $67(48.6 \%)$ & $9(31 \%)$ & $58(53.2 \%)$ & \\
\hline$<60$ & $71(51.4 \%)$ & $20(69 \%)$ & $51(46.8 \%)$ & \\
\hline Stone size, mm, median (IOR) & $13 \pm 6.2$ & $15.5 \pm 5.7$ & $12.4 \pm 6.2$ & 0.016 \\
\hline Stone number, median (IOR) & & & & 0.263 \\
\hline Upper ureteral & $41(2.7 \%)$ & $8(27.6 \%)$ & $33(30.3 \%)$ & \\
\hline Middle ureteral & $24(17.4 \%)$ & $3(10.3 \%)$ & $21(19.3 \%)$ & \\
\hline Distal ureteral & $55(39.9 \%)$ & $13(44.8 \%)$ & $42(38.5 \%)$ & \\
\hline Multiple & $12(8.7 \%)$ & $4(13.8 \%)$ & $8(7.3 \%)$ & \\
\hline Renal pelvis & $6(4.3 \%)$ & $1(3.4 \%)$ & $5(4.6 \%)$ & \\
\hline Preoperative Double-J stent, \% & $42(30.4 \%)$ & $8(27.6 \%)$ & $34(31.2 \%)$ & 0.708 \\
\hline Positive preoperative urine culture, $\%$ & $19(13.8 \%)$ & $9(31 \%)$ & $10(9.2 \%)$ & 0.004 \\
\hline Positive preoperative MDR urine culture, $\%$ & $11(8 \%)$ & $6(20.7 \%)$ & $5(4.6 \%)$ & 0.011 \\
\hline History of previous stone treatment, $\%$ & & & & 0.82 \\
\hline Operation time, minutes, median (IOR) & $69.7 \pm 26.9$ & $81.6 \pm 34.7$ & $66.6 \pm 23.6$ & 0.01 \\
\hline Preoperative double-J stent, $\%$ & $42(30.4 \%)$ & $8(27.6 \%)$ & $34(31.2 \%)$ & 0.708 \\
\hline Postoperative double-J stent, $\%$ & $103(76.4 \%)$ & $27(93.1 \%)$ & $76(69.7 \%)$ & 0.01 \\
\hline Hospitalization time, days, median (IOR) & $4.4 \pm 2.4$ & $4.7 \pm 2.7$ & $4.3 \pm 2.3$ & 0.342 \\
\hline Presence of residual fragments, $\%$ & $40(29 \%)$ & $8(27.6 \%)$ & $32(29.9 \%)$ & 0.852 \\
\hline Renal anatomical anomaly, $\%$ & $7(5.1 \%)$ & $1(3.4 \%)$ & $6(5.5 \%)$ & 0.654 \\
\hline Hydronephrosis, \% & & & & 0.15 \\
\hline None or mild & $96(69.6 \%)$ & $17(58.6 \%)$ & $79(72.5 \%)$ & \\
\hline Moderate or severe & $42(30.4 \%)$ & $12(41.4 \%)$ & $30(27.5 \%)$ & \\
\hline
\end{tabular}

medical complexity, and positive preoperative urine cultures. This is one of the largest investigations in this age gathering analyzing risk factors for POF/SIRS after RURSLL.

Stone disease is an increasing, expensive chronic condition and seeks medical advice $(18,19)$. URS is an alternative for treatment of stones $<1 \mathrm{~cm}$ and has grown exponentially over the past decades (20-22). Although URS complications are rare, POF is the most common complication that requires more emergency visits and unplanned admissions $(10,13,23,24)$. Tantamount to revealed rates, we discovered that $6.9 \%$ of URS cases were either seen in the emergency unit or readmitted for POF/SIRS (25). Our outcomes expand on earlier investigations of POF, SIRS, and other post-URS infectious complications. In spite of the fact that no standard description of post-URS infectious complications exists, medical complexity, longer operative time, and preoperative pyuria, or positive culture have all been noted 


\begin{tabular}{|c|c|c|c|}
\hline Multivariate analysis & OR & $95 \% \mathrm{Cl}$ & $\mathbf{p}$ \\
\hline Body mass index & 1.15 & $1.03-1.29$ & 0.016 \\
\hline ACCI & 1.67 & $0.96-2.89$ & 0.068 \\
\hline Positive preoperative urine culture & 8.36 & $2.20-31.79$ & 0.002 \\
\hline
\end{tabular}

as hazard factors in studies utilizing an assortment of outcome definitions. In 1,325 cases from the Clinical Research Office of the Endourological Society (CROES) URS Global Study Database, female gender and medical complexity were found to be the predictive factors of POF or urinary tract infection (UTI), even in the lack of a positive preoperative urinary culture (26). Another research confirmed these results in 927 URS procedures, 286 of which were carried out in females. The authors observed an important distinction between males (1\%) and females (3\%) in the incidence of febrile UTI (27). While it is not apparent why females are more likely to experience infectious complications after URS, this may be due to the short urethral length or ambient bacteria. However, we could not see such a distinction in gender in our research.

Similar to other research, we discovered that POF/SIRS requires longer operation time. Owing to stone characteristics, operation time can be a proxy for surgical complexity (28). Kuroda et al. (29) created a model based on a cohort of 972 patients to anticipate URS operation time. Preoperative stenting, stone volume, Hounsfield units, specialist experience, gender, and small-sized sheaths anticipated longer operation times. We think that most of the preoperative and intraoperative features in our research were insignificant as they contribute to longer surgical time jointly. Other research showed the association between longer operation times and POF. A research of 550 patients showed that URS operation times of more than 120 minutes were correlated with unplanned infection yields, although the confidence intervals were wide, probably owing to the small number of results (23).

In debates on the hazards and advantages of urological procedures, aging and medical complexity are significant factors (30). In 11,719 patients from the CROES URS Global Study Database, the writers observed that elderly, medically complicated, and anticoagulant users were more likely to have postoperative complications (3.5\%), 75\% of which were fever, UTI, or other problems (31). In a cohort of 276 URS, patients with two or more comorbidities were at a greater risk of readmission, and readmission was substantially related with hypertension or asthma/chronic obstructive pulmonary disease (24). In our cohort study, as it included the geriatric community, the mean comorbidity index was 2.7. On the other hand, like other research, however, the mean $\mathrm{CCl}$ score in the POF/SIRS group was considerably higher.

Positive preoperative urine culture was the most important modifiable predictor from our cohort. Multiple studies discovered that preoperative pyuria or positive urine cultures were correlated with URS-related infectious complications, although lower cohort sizes ranged from 100 to 500 patients. The biggest cohort had 532 patients and discovered that $3.8 \%$ had infectious problems with the risk factors including preoperative bacteriuria, hydronephrosis, and foreign bodies in the urinary tract (32). In another cohort of 153 patients, 18.3\% experienced febrile UTI, and one of the most important factors was preoperative pyuria (33). These findings correspond with those of Margel et al. who discovered that 19 of 75 (25\%) percutaneous nephrolithotomytreated patients with a positive stone culture had sterile urine, and urine culture sensitivity to predict stone colonization was only 30\% (34). Moreover, antibiotic prophylaxis used in this study did not eliminate the risk of infection after FURSLL in 30 of $433(6.9 \%)$ patients with negative preoperative urine cultures. Indeed, in the CROES-URS Global Study, Martov et al. (26) showed that rates of postoperative UTI and fever were not reduced by preoperative antibiotic prophylaxis in patients who underwent URS for ureteral stones $(n=1141)$ or kidney stones $(n=184)$. Possible reasons for these results might be that urine cultures may not correctly represent the pathogens responsible for the infection found in the upper urinary tract or in infected stones and may not be able to thoroughly penetrate the infected stone (35). A declaration of best practice by the American Urological Association (AUA) proposes perioperative antimicrobial prophylaxis for all patients undergoing URS owing to the hazard of bacteremia from stone manipulation and upper tract endoscopy (36).

Stent insertion is an efficient technique for acute drainage of hydronephrotic or pyonephrotic kidneys (37). In contrast, it may be the long-term cause of the infection. Several trials revealed colonization rates of ureteral stents from $44 \%$ to $69 \%$ and bacteriuria rates from $21 \%$ to $29.9 \%$. Because of bacterial colonization of DJ stents (38), mild fever, UTI, and even sepsis can be seen. POF was observed in 22 (25\%) patients who had 
no preoperative fever in a research undertaken with 87 patients who had DJ stent insertion following urgent intervention $(n=34)$ or elective intervention $(n=53)$. Fever was observed in 56\% of patients who had stent insertion after emergency intervention, while it was present in only $6 \%$ of patients who had stent insertion after elective intervention. Therefore, stent insertion was revealed to significantly increase the risk of fever after emergency intervention (39). In another research, 26 of the 48 patients underwent URS due to distal ureteral stone was placed with DJ stent, and 22 patients were followed up without a stent. In just one patient who had DJ stent insertion, urosepsis was discovered and the distinction was not significant (40). A comparable research found that there was no association between fever and stent insertion (41). Ibrahim et al. (42) prospectively evaluated 110 stent patients and 110 non-stent patients in their big sequence. Fever developed in $8(7.3 \%)$ patients and UTIs found in $5(4.5 \%)$ patients in the stent group, whereas fever occurred in $10(9.1 \%)$ instances and UTIs occurred in 7 (6.4\%) instances in the non-stented group. Even though there was no significant distinction between the groups, fever and infection in the unstented group were slightly higher. In this study, after RURSLL, we discovered fever rates in the stented group were significantly higher. We could not interpret whether our results depended on age because only the geriatric age population was included in our research group. This complication can be caused by medical complexity, which should be studied.

For asymptomatic individuals, it is not our normal practice to acquire urine cultures regardless of symptoms before URS similar to AUA guidelines that suggest urinalysis alone (20). The perioperative antibiotic is tailored to the bacterial organism and susceptibility, according to the results of the antibiogram. A 3-day regimen of antibiotic with genitourinary coverage (e.g., cephalexin) or 5-7 days of nitrofurantoin is our postoperative regimen. Some patients still develop infectious complications in spite of this standard approach. In order to comprehend the pathophysiology and how to decrease the hazard of this complication, further study is required.

\section{Study Limitations}

Our study has some built-in limitations. First, this is a retrospective observational study in a gathering of geriatric patients who underwent RURSLL. Second, there is no standard definition of infectious complications, and we concentrated on POF/SIRS, which results in expensive use of health care. Third, no complete data on stone compound, stone culture, and urine culture of the upper urinary tract were available. Finally, we did not consider the possible effect of intraoperative fluid irrigation pressure on postoperative infectious complications.

\section{Conclusions}

In this research of RURSLL among geriatric population, we discovered that the most important predictors of POF/SIRS were longer operation times, positive preoperative urine cultures, and postoperative insertion of DJ stent. These data indicate that the procedure should be kept as short as possible, and the indications for postoperative DJ catheter insertion should be reduced as much as possible in geriatric patients. This information will assist suppliers to identify the high-risk people and guide them on assessment of risk factors to reduce the rate of POF/SIRS. Future studies will concentrate on how to protect at-risk patients from infectious complications.

\section{Ethics}

The study were approved by the Bulent Ecevit University Faculty of Medicine, Department of Urology Local Ethics Committee (protocol number: 2019-84-22/05, date: 22.05.2019).

Informed Consent: Informed consent was obtained before oparation from all individual participants included in the study.

Peer-review: Externally peer-reviewed.

\section{Authorship Contributions}

Surgical and Medical Practices: R.G., E.D.D., Concept: R.G., E.D.D., Design: R.G., E.D.D., Data Collection or Processing: R.G., E.D.D., Analysis or Interpretation: R.G., E.D.D., Literature Search: R.G., E.D.D., Writing: R.G., E.D.D.

Conflict of Interest: No conflict of interest was declared by the authors.

Financial Disclosure: The authors declared that this study received no financial support.

\section{References}

1. Chatterji S, Byles J, Cutler D, Seeman T, Verdes E. Health, functioning, and disability in older adults--present status and future implications. Lancet 2015;385:563-575.

2. McCarthy JP, Skinner TAA, Norman RW. Urolithiasis in the elderly. Can J Urol $2011 ; 18: 5717-5720$.

3. Hu H, Lu Y, He D, Cui L, Zhang J, Zhao Z, Qin B, Wang Y, Lin F, Wang S. Comparison of minimally invasive percutaneous nephrolithotomy and flexible ureteroscopy for the treatment of intermediate proximal ureteral and renal stones in the elderly. Urolithiasis 2016;44:427-434.

4. Tonner PH, Kampen J, Scholz J. Pathophysiological changes in the elderly. Best Pract Res Clin Anaesthesiol 2003;17:163-177.

5. Turk C, Knoll T, Petrik A, Sarica K, Skolarikos A, Straub M, Seitz C. Guidelines on urolithiasis. Arnhem (NL): European Asso $\neg$ ciation of Urology 2015.

6. Busby JE, Low RK. Ureteroscopic treatment of renal calculi. Urol Clin North Am 2004;31:89-98.

7. Karlsen SJ, Renkel J, Tahir AR, Angelsen A, Diep LM. Extracorporeal shockwave lithotripsy versus ureteroscopy for 5- to 10-mm stones in 
the proximal ureter: Prospective effectiveness patient-preference trial. J Endourol 2007;21:28-33.

8. Kumar A, Nanda B, Kumar N, Kumar R, Vasudeva P, Mohanty NK. A prospective randomized comparison between shock $\neg$ wave lithotripsy and semirigid ureteroscopy for upper ureteral stones $<2 \mathrm{~cm}$ : a single center experience. J Endourol 2015;29:47-51.

9. de la Rosette J1, Denstedt J, Geavlete P, Keeley F, Matsuda T, Pearle M, Preminger G, Traxer 0; CROES URS Study Group. The Clinical Research Office of the Endourological Society Ureteroscopy Global Study: Indications, Complications, and Outcomes in 11,885 Patients. J Endourol 2014;28:131-139.

10. Somani BK, Giusti G, Sun Y, Osther PJ, Frank M, De Sio M, Turna B, de la Rosette J. Complications associated with ureterorenoscopy (URS) related to treatment of urolithiasis: the Clinical Research Office of Endourological Society URS Global study. World J Urol 2017;35:675-681.

11. Johnson DB, Pearle MS. Complications of ureteroscopy. Urologic Clinics 2004;31:157-171.

12. Blackmur JP, Maitra NU, Marri RR, Housami F, Malki M, Mcllhenny C. Analysis of Factors' Association with Risk of Postoperative Urosepsis in Patients Undergoing Ureteroscopy for Treatment of Stone Disease. J Endourol 2016;30:963-969.

13. Du K, Wang R, Vetter J, Paradis AG, Figenshau RS, Venkatesh R, Desai AC. Unplanned 30-day encounters after ureterorenoscopy for urolithiasis. Juro. 2017;197(Supp):1004. doi:10.1016/j.juro.2017.02.2151.

14. https://pubmed.ncbi.nlm.nih.gov/30156428/

15. Moses RA, Ghali FM, Pais VM Jr, Hyams ES. Unplanned Hospital Return for Infection following Ureteroscopy-Can We Identify Modifiable Risk Factors? J Urol 2016;195:931-936. Bloom J, Matthews G, Phillips J. Factors Influencing Readmission after Elective Ureteroscopy. J Urol 2016;195:1487-1491.

16. Zhong W, Leto G, Wang L, Zeng G. Systemic inflammatory response syndrome after flexible ureteroscopic lithotripsy: a study of risk factors. J Endourol 2015;29:25-28.

17. Wagenlehner FM, Lichtenstern C, Rolfes C, Mayer K, Uhle F, Weidner W, Weigand MA. Diagnosis and management for urosepsis. Int J Urol 2013;20:963-970

18. Foster G, Stocks C, Borofsky MS. Emergency Department Visits and Hospital Admissions for Kidney Stone Disease, 2009: Statistical Brief \#139. July 2012:1-10.

19. Strohmaier WL. Economics of stone disease/treatment. Arab J Uro 2012;10:273-278.

20. Assimos D, Krambeck A, Miller NL, Monga M, Murad MH, Nelson CP, Pace KT, Pais VM Jr, Pearle MS, Preminger GM, Razvi H, Shah O, Matlaga BR. Surgical Management of Stones: American Urological Association/Endourological Society Guideline, PART I. J Urol 2016;196:1153-1160.

21. Assimos D, Krambeck A, Miller NL, Monga M, Murad MH, Nelson CP, Pace KT, Pais VM Jr, Pearle MS, Preminger GM1, Razvi H, Shah 0, Matlaga BR. Surgical Management of Stones: American Urological Association/Endourological Society Guideline, PART II. J Urol 2016;196:1161-1169.

22. Turney BW, Reynard JM, Noble JG, Keoghane SR. Trends in urological stone disease. BJU Int 2011;109:1082-1087.

23. Moses RA, Ghali FM, Pais VM Jr, Hyams ES. Unplanned Hospital Return for Infection following Ureteroscopy-Can We Identify Modifiable Risk Factors? J Urol 2016;195:931-936.

24. Bloom J, Matthews G, Phillips J. Factors Influencing Readmission after Elective Ureteroscopy. J Urol 2016;195:1487-1491.

25. Fan S, Gong B, Hao Z, Zhang L, Zhou J, Zhang Y, Liang C. Risk factors of infectious complications following flexible ureteroscope with a holmium laser: a retrospective study. Int J Clin Exp Med 2015;8:11252-11259.

26. Martov A1, Gravas $S$, Etemadian $M$, Unsal A, Barusso G, D'Addessi $A$ Krambeck A, de la Rosette J; Clinical Research Office of the Endourological Society Ureteroscopy Study Group. Postoperative Infection Rates in Patients with a Negative Baseline Urine Culture Undergoing Ureteroscopic Stone Removal: A Matched Case-Control Analysis on Antibiotic Prophylaxis from the CROES URS Global Study. J Endourol 2015;29:171-180.

27. Özsoy M, Acar Ö, Sarica K, Saratlija-Novakovic Z, Fajkovic H, Librenjak D, Esen T, Scheffbuch N, Seitz C. Impact of gender on success and complication rates after ureteroscopy. World J Urol 2015;33:1297-1302.

28. Schuster TG, Hollenbeck BK, Faerber GJ, Wolf JS. Complications of ureteroscopy: analysis of predictive factors. J Urol 2001;166:538-540.

29. Kuroda S, Ito H, Sakamaki K, Tabei T, Kawahara T, Fujikawa A, Makiyama K, Yao $M$, Uemura $H$, Matsuzaki J. A new prediction model for operative time of flexible ureteroscopy with lithotripsy for the treatment of renal stones. PLoS ONE 2018;13:e0192597.

30. Garg T, Young AJ, Kost KA, Danella JF, Larson S, Nielsen ME, Kirchner HL. Burden of Multiple Chronic Conditions among Patients with Urological Cancer. J Urol 2018;199:543-550.

31. Daels FP, Gaizauskas A, Rioja J, Varshney AK, Erkan E, Ozgok Y, Melekos M, de la Rosette JJ. Age-related prevalence of diabetes mellitus, cardiovascular disease and anticoagulation therapy use in a urolithiasis population and their effect on outcomes: the Clinical Research Office of the Endourological Society Ureteroscopy Global Study. World J Urol 2015:1-6.

32. Sohn DW, Kim SW, Hong CG, Yoon II B, Ha U-S, Cho Y-H. Risk factors of infectious complication after ureteroscopic procedures of the upper urinary tract. J Infect Chemother 2013;19:1102-1108.

33. Mitsuzuka K, Nakano O, Takahashi N, Satoh M. Identification of factors associated with postoperative febrile urinary tract infection after ureteroscopy for urinary stones. Urolithiasis 2015;44:257-262.

34. Margel D, Ehrlich Y, Brown N, Lask D, Livne PM, Lifshitz DA. Clinical implication of routine stone culture in percutaneous nephrolithotomy--a prospective study. Urology 2006;67:26-29.

35. Korets R, Graversen JA, Kates M, Mues AC, Gupta M. Post-percutaneous nephrolithotomy systemic inflammatory response: a prospective analysis of preoperative urine, renal pelvic urine and stone cultures. J Urol 2011;186:1899-1903.

36. Wolf JS Jr, Bennett CJ, Dmochowski RR, Hollenbeck BK, Pearle MS, Schaeffer AJ; Urologic Surgery Antimicrobial Prophylaxis Best Practice Policy Panel. Best practice policy statement on urologic surgery antimicrobial prophylaxis. J Urol 2008;179:1379-1390.

37. Goldsmith ZG, Oredein-McCoy O, Gerber L, Bañez LL, Sopko DR, Miller MJ, Preminger GM, Lipkin ME. Emergent ureteric stent vs percutaneous nephrostomy for obstructive urolithiasis with sepsis: patterns of use and outcomes from a 15-year experience. BJU Int 2013;112:122-128.

38. Paick SH, Park HK, Oh SJ, Kim HH. Characteristics of bacterial colonization and urinary tract infection after indwelling of double $\mathrm{j}$ ureteral stent Urology 2003;62:214-217.

39. Paz A, Amiel GE, Pick N, Moskovitz B, Nativ O, Potasman I. Febrile complications follow-ing insertion of 100 double J ureteral stents. J Endourol 2005;19:147-150.

40. Srivastava A, Gupta R, Kumar A, Kapoor R, Mandhani A. Routine stenting after ureteroscopy for distal ureteral calculi is unnecessary: results of a randomized controlled trial. J Endourol 2003;17:871-874.

41. Cevik I, Dillioglugil 0 , Akdas A, Siegel Y. Is stent placement necessary after uncomplicated ureteroscopy for removal of impacted ureteral stones? J Endourol 2010;24:1263-1267.

42. Ibrahim HM, Al-Kandari AM, Shaaban HS, Elshebini YH, Shokeir AA. Role of ureteral stenting after uncomplicated ureteroscopy for distal ureteral stones: a randomized, controlled trial. J Urol 2008;180:961-965. 